\begin{tabular}{|c|c|c|c|c|c|}
\hline JRL & Vol. 12 & No.2 & Hal : 175-184 & $\begin{array}{c}\text { Jakarta, } \\
\text { Desember 2019 }\end{array}$ & $\begin{array}{c}\text { p-ISSN : 2085.38616 } \\
\text { e-ISSN : 2580-0442 }\end{array}$ \\
\hline
\end{tabular}

\title{
Aspek Mikrobiologi dalam Pengolahan Air Siap Minum Menggunakan Membran Reverse Osmosis
}

\author{
Joko Prayitno \\ Pusat Teknologi Lingkungan, BPPT, Gedung 820 Geostech, Kawasan \\ PUSPIPTEK Serpong, Tangerang Selatan \\ Email : joko.prayitno@bppt.go.id
}

\begin{abstract}
Abstrak
Teknologi reverse osmosis (RO) sudah banyak digunakan untuk mengolah air baku menjadi air siap minum (ARSINUM). Masalah yang sering dijumpai dalam proses pengolahan air baku untuk ARSINUM menggunakan RO diantaranya adalah keberadaan mikroorganisme dari air proses dan pembentukan biofilm. Mikroorganisme yang lolos dari membran RO dan bertahan dari perlakuan desinfektan dapat berkembangbiak dan menjadi sumber kontaminan. Karena itu, kualitas ARSINUM yang dihasilkan, khususnya dari aspek mikrobiologi, perlu dikontrol secara periodik untuk memastikan ARSINUM itu aman untuk dikonsumsi. Dalam makalah ini dibahas mengenai permasalahan yang dijumpai dalam aplikasi teknologi RO untuk produksi ARSINUM dari aspek mikrobiologi dan beberapa alternatif untuk penanggulangannya.
\end{abstract}

Kata Kunci : reverse osmosis, air minum, mikroorganisme, biofilm

\section{Microbiological Aspect of Drinking Water Production Using Reverse Osmosis Membrane}

\begin{abstract}
Reverse osmosis (RO) technology has been widely used to process raw water for drinking water. One of the common problems using $R O$ for drinking water processing is the presence of microorganisms in produce water and the accumulation of biofilm on the membrane. Microorganisms in the produce water survived from desinfection treatments could grow and contaminate the drinking water. Therefore, water quality from RO should be periodically checked for any microbial contamination to ensure the drinking water is safe for consumption. In this paper, two most common microbiological-related problems of drinking water from $R O$ membrane as well as their preventive measures were discussed.
\end{abstract}

Keywords : reverse osmosis, drinking water, microorganisms, biofilms. 


\section{Pendahuluan}

Pemanfaatan teknologi membran reverse osmosis (RO) untuk mengolah air baku menjadi air siap minum (ARSINUM) saat ini sudah umum digunakan di berbagai negara. Membran RO mampu menghilangkan partikel dan ion dalam air umpan sehingga banyak digunakan untuk memurnikan air dan desalinasi. Salah satu tujuan dari pemanfaatan RO untuk ARSINUM adalah menghilangkan cemaran mikrobiologi seperti bakteri dan virus dari air produksi.

Meskipun teknologi RO untuk pengolahan ARSINUM sudah cukup maju, masih ada beberapa isu yang perlu diatasi agar ARSINUM yang dihasilkan dapat dikonsumsi dengan aman dalam jangka panjang dan biaya produksi dapat ditekan seminimal mungkin. Isu-isu tersebut adalah masalah kandungan bakteri patogen dalam ARSINUM dan masalah biofouling dalam produksi ARSINUM skala besar.

Isu kandungan bakteri patogen dalam ARSINUM terkait dengan aspek kesehatan masyarakat. Karena itu aspek kesehatan dari penyediaan ARSINUM ini merupakan bagian penting selain pengembangan teknologi ARSINUM itu sendiri. Pemerintah telah menetapkan peraturan mengenai baku mutu air minum, khususnya kandungan bakteri yang berasal dari tinja yaitu Eschericia coli dan sejenisnya (coliform). Berdasarkan Permenkes No. 492/MENKES/PER/ IV/2010, baku mutu air minum yang disyaratkan adalah tidak mengandung E. coli maupun coliform (jumlah sel E. coli dan coliform dalam $100 \mathrm{~mL}$ air adalah nol). Parameter bakteri patogen seperti Pseudomonas, Stapylococcus dan Legionella dan virus tidak termasuk dalam peraturan kualitas untuk air minum hingga saat ini.

Saat ini, pemanfaatan teknologi membran $\mathrm{RO}$ yang dikombinasikan dengan perlakuan sinar ultraviolet (UV) pada unit ARSINUM untuk skala komunal mulai banyak digunakan di Indonesia khususnya di wilayah yang mengalami kesulitan air bersih atau daerah yang jauh dari wilayah perkotaan. Demikian pula mesin ARSINUM sudah banyak tersedia di berbagai lokasi fasilitias umum. $\mathrm{RO}$ pada unit ARSINUM dapat menghilangkan bakteri dari air yang bersumber dari kran (air PAM) (Park dan Hu, 2010; Fujioka et al., 2018). ARSINUM skala komunal ini dapat terkontaminasi kembali oleh mikroorganisme patogen bila tidak dilakukan pemeliharaan dengan baik secara berkala. Beberapa studi melaporkan bahwa ARSINUM dari unit pengolah air minum di beberapa tempat tercemar oleh mikroorganisme termasuk bakteri koliform, bakteri heterotrof dan Pseudomonas (AI Moosa et al. 2015; Hashim dan Yusop, 2016; Yongyod, 2018, Wibuloutai, 2019; Liguori, 2010).

Masalah lain yang dijumpai dalam aplikasi teknologi membran RO untuk menghasilkan ARSINUM adalah biofouling (Goosen et al., 2005; Bixler dan Bushan, 2012). Biofouling diartikan sebagai pembentukan lapisan mikroba yang tidak diinginkan pada permukaan membran $\mathrm{RO}$ yang dapat menghambat aliran air melalui pori membran sehingga mengganggu proses filtrasi air baku menjadi air produksi. Biofouling ditemukan baik pada sistem penyediaan ARSINUM skala besar untuk konsumsi 
perkotaan maupun unit ARSINUM skala rumah tangga, meskipun masalah tersebut tidak terlalu signifikan untuk sistem RO skala rumah tangga karena membran dapat diganti secara berkala.

Dalam makalah ini, aspek mikrobiologi dari pengolahan ARSINUM menggunakan RO yang dikaji meliputi efektifitas penghilangan mikroorganisme menggunakan $\mathrm{RO}$, faktor-faktor yang mempengaruhinya dan upaya-upaya untuk mengatasinya, serta masalah biofouling dan teknologi yang dikembangkan hingga saat ini untuk mengatasinya. Makalah ini membahas tentang proses yang terlibat dalam biofouling dan produk yang digunakan untuk menghilangkannya.

\section{Metode}

Metode yang digunakan adalah penelusuran data sekunder dari hasil publikasi di berbagai jurnal ilmiah, buku, serta laporan teknis yang selanjutnya diolah dan disajikan dalam bentuk gambar.

\section{Hasil dan Pembahasan}

\section{Efektifitas Penghilangan mikroorganisme oleh RO}

Ditinjau dari aspek mikrobiologi, kualitas ARSINUM yang diperoleh selama proses produksi dan distribusi mengalami variasi dari waktu ke waktu (El-Chakhtoura et al., 2015), khususnya dalam hal kelimpahan sel bakteri. Keberadaan bakteri dalam air produksi yang telah dilaporkan umumnya berada dalam kisaran $10^{3}$ $10^{6} \mathrm{sel} / \mathrm{mL}$ (Prest et al., 2016; Douterelo et al., 2019; Potgieter et al., 2018). Keberadaan mikroorganisme dalam air produksi hasil filtrasi $\mathrm{RO}$ juga terdeteksi berdasarkan pantauan real-time online monitoring menggunakan cahaya autofluoresens yang dipancarkan oleh molekul riboflavin dan NADH dari mikroorganisme. Cahaya autofluoresens yang terdeteksi ini dapat membedakan bakteri dengan partikel non-bakteri. Dari pantauan secara real-time ini, jumlah sel bakteri yang terdeteksi pada air baku adalah 4,54 log hingga 5,30 log sel/mL, sedangkan dalam air proses adalah 2,70 log hingga 3,11 log $\mathrm{sel} / \mathrm{mL}$ (Fujioka et al., 2018).

Keberadaan bakteri patogen dalam ARSINUM menjadi perhatian karena banyak jenis bakteri patogen yang dapat tumbuh dalam ARSINUM yang memilik kandungan nutrien sangat rendah. Bakteri tersebut ditemukan di permukaan pipa berupa biofilm, atau di dalam air produksi. Selain berpengaruh terhadap aspek kesehatan, keberadaan bakteri dalam ARSINUM juga dapat mempengaruhi rasa dan bau karena dihasilkan senyawa penyebab bau dan rasa hasil metabolisme senyawa tertentu oleh bakteri (Zhou et al,. 2017).

Keberadaan bakteri dalam air produksi menimbulkan pertanyaan mengenai efektifitas penghilangan bakteri oleh RO. Efektifitas penghilangan bakteri dilaporkan mencapai lebih dari 99\% (Park dan Hu, 2010; Prest et al., 2016; Penna et al., 2016; Fujioka et al., 2019). Dengan demikian masih ada sebagian kecil bakteri yang lolos dari membran RO. Penghilangan bakteri yang tidak sempurna tersebut juga dilaporkan pada membran nanofiltrasi yang berupa lembaran spiral (Laurent et al., 1999; Park dan Hu, 2010).

Hal yang menjadi pertanyaan hingga kini adalah bagaimana sel-sel bakteri tersebut dapat lolos melewati 
membran RO. Ukuran pori dari membran RO bervariasi mulai dari 0.1 nm atau lebih (Fujioka et al., 2013), sedangkan sel bakteri berukuran lebih dari $200 \mathrm{~nm}$, sehingga secara teori sel bakteri akan tertahan di membran RO.

Beberapa kemungkinan lolosnya bakteri dari proses filtrasi membran $\mathrm{RO}$ adalah pada sambungan antara membran dengan tangki wadah (cartridge) yang dilengkapi seal Ring$\mathrm{O}$ dan pada membran $\mathrm{RO}$ itu sendiri (Fujioka et al., 2018). Sambungan yang dilengkapi dengan Ring-O ini memisahkan antara air baku bertekanan tinggi dengan air produksi yang bertekanan rendah.

Studi yang dilakukan oleh Penna et al. (2002) menunjukkan bahwa sampel air yang diambil dari beberapa titik dalam proses pengolahan ARSINUM, termasuk titik setelah perlakuan UV (titik 9) dan setelah melewati tiga unit membran filtrasi berukuran 0,05 $\mu \mathrm{m}$ yang disusun paralel (titik 10, setelah melewati titik 9) mengandung 27-87 cfu/100 mL (Penna et al., 2002). Bakteri tersebut diantaranya adalah Synergistetes, Firmicutes, Bacteroidetes dan Proteobacteria (Beilla et al., 2016), Pseudomonas, Flavobacterium, dan Acinetobacter (Penna et al., 2002). Belila et al. (2016) menemukan bahwa struktur komunitas bakteri di air umpan berbeda dari air produksi, mengindikasikan bahwa komunitas bakteri berubah seiring dengan perubahan kualitas air. Komunitas bakteri tersebut tidak berubah setelah melewati membran dan selama berada dalam pipa distribusi (El Chaktoura et al., 2015).

Hal yang mempengaruhi kualitas ARSINUM, khususnya terkait dengan keberadaan bakteri dalam ARSINUM, adalah kualitas air baku dan disain dari mesin ARSINUM (Farhadkhani et al., 2014). Komponen dari sistem produksi ARSINUM yang memiliki peluang ditemukannya bakteri adalah sistem filtrasi, tangki penyimpanan, sistem perpipaan, dan kran dispenser air minum (Yongyod, 2018; Pratum dan Khananthai, 2017). Hasil penelitian Pratum dan Khananthai (2017) menunjukkan bahwa coliform yang dijumpai pada kran ARSINUM dipengaruhi oleh jumlah kran dispenser yang terpasang, semakin banyak jumlah kran air minum maka semakin banyak ditemukan bakteri di lokasi tersebut. Hal ini mengindikasikan bahwa salah satu sumber kontaminasi ARSINUM oleh bakteri adalah celah terbuka dalam hal ini permukaan kran, khususnya bila permukaan kran dispenser jarang dibersihkan (Liguori et al., 2010).

Keberadaan bakteri dalam tanki penyimpanan ARSINUM disebabkan karena kondisi wadah atau lingkungan sekitar ARSINUM yang memungkinkan bakteri untuk masuk dan mengkontaminasi air minum. Dengan demikian air minum yang sudah lama tersimpan dalam wadah ARSINUM lebih terkontaminasi oleh bakteri dibandingkan dengan air minum yang baru difiltrasi menggunakan RO (Yongyod, 2018). Hal lain yang menarik untuk dicermati adalah lokasi penempatan dispenser ARSINUM juga berpengaruh terhadap tingkat kontaminasi bakteri di ARSINUM. Jumlah unit pengolah ARSINUM yang ditempatkan di luar ruangan lebih banyak yang terkontaminasi bakteri dibandingkan dengan unit pengolahan ARSINUM yang ditempatkan di dalam ruangan (Pratum dan Khananthai, 2017).

Keberadaan bakteri dalam unit dispenser air minum juga dilaporkan oleh Al Moosa et al. (2015). Dari 49 sampel ARSINUM yang diteliti, 6 
diantara mengandung coliform dan 19 sampel mengandung $P$. aeruginosa.

Berdasarkan hasil penelitian Baba et al. (2009), dalam air baku untuk RO skala industri yaitu air yang berasal dari efluen IPAL lumpur aktif banyak ditemukan bakteri dari jenis Simonsiella sp., sedangkan dalam air proses banyak ditemukan bakteri Bosea sp. dan Rhizobium sp. Hasil ini menunjukkan bahwa monitoring air hasil RO secara mikrobiologi perlu dilakukan secara rutin khususnya untuk menjaga kualitas air RO yang dihasilkan. Hal ini juga dilakukan sebagai sistem peringatan dini akan potensi masalah kontaminasi dan cara mengontrol keberadaan bakteri tersebut dalam sistem air RO.

\section{Biofilm di RO dan Pipa Distribusi}

Biofilm yang terbentuk dalam membran RO menimbulkan masalah yang cukup serius dalam unit pengolahan ARSINUM karena kinerja dan efisiensi sistem RO akan menurun. Pengetahuan mengenai komposisi mikroba biofilm dalam $\mathrm{RO}$ dan kaitannya dengan kondisi operasi RO dapat digunakan untuk mengetahui proses pembentuk-an biofilm sehingga dapat dibuat strategi penanggulangannya. Metode pemantauan komposisi komunitas mikroba yang cukup sensitif adalah metode molekuler. Namun demikian metode pengkulturan bakteri masih tetap digunakan hingga saat ini untuk mengetahui komposisi mikroba, meskipun metode ini tidak dapat menggambarkan keragaman komunitas bakteri dalam membran $\mathrm{RO}$ dengan detil.

Jenis bakteri yang paling umum diteliti keberadaanya dalam ARSINUM adalah coliform dan E. coli. $\mathrm{Hal}$ ini disebabkan karena metode pembiakan jenis bakteri tersebut relatif lebih mudah dan murah dan menjadi acuan dalam standar kesehatan kualitas air minum. Namun demikian, keberadaan jenis bakteri lain juga telah banyak dilaporkan. Bakteri yang umum dijumpai pada membran RO adalah Acinetobacter, Pseudomonas, Alcaligenes, Corynebacterium, dan Flavobacterium.

Biofilm juga terbentuk dalam saluran distribusi air minum yang telah difiltrasi dengan membran $\mathrm{RO}$ (Gambar 1). Biofilm terbentuk dalam periode waktu tertentu setelah sel-sel bakteri yang melekat di permukaan dinding pipa tumbuh. Sel-sel bakteri tersebut pada awalnya akan mengeluarkan senyawa eksopolisakarida (EPS) sehingga selsel tersebut melekat satu sama lain. Setelah mencapai populasi tertentu, maka terbentuk biofilm pada permukaan dinding pipa. Biofilm yang terbentuk ini menjadi salah satu sumber keberadaan bakteri dalam ARSINUM. 


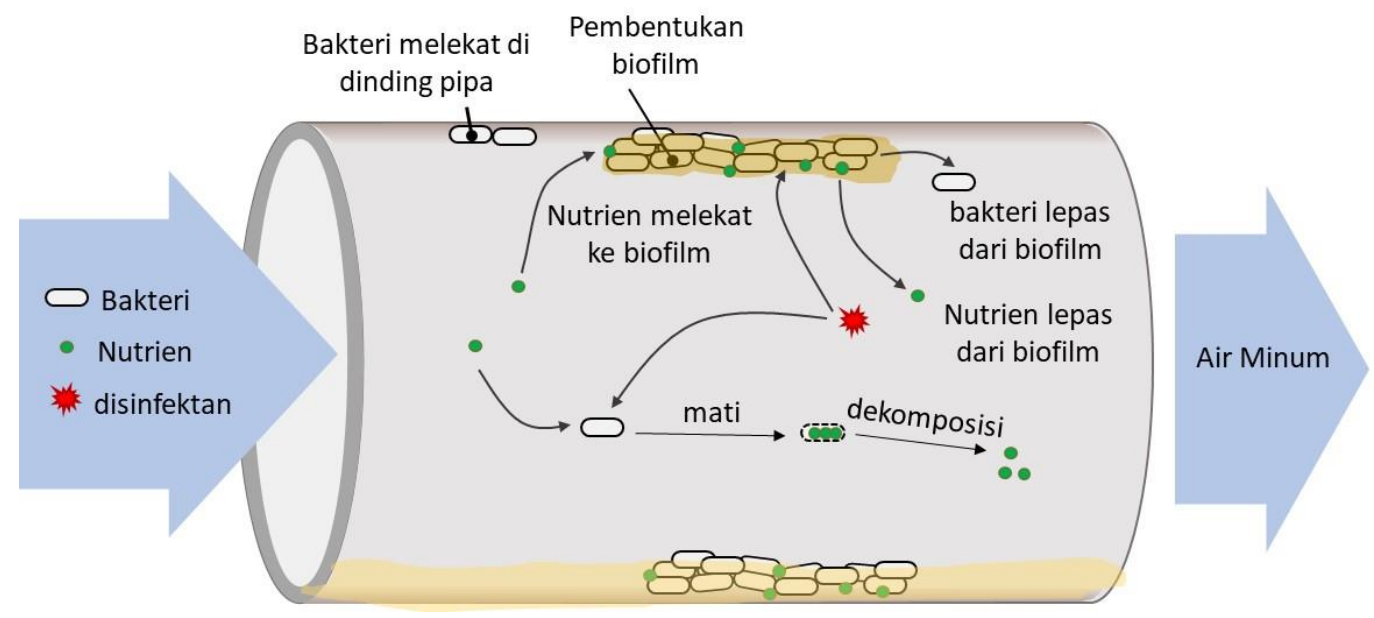

Gambar 1. Dinamika pertumbuhan bakteri dalam pipa air minum (Diadaptasi dari Prest et al., 2016)

\section{Masalah Biofouling}

Biofouling diartikan sebagai pembentukan lapisan mikroba yang tidak diinginkan pada permukaan membran RO. Semua sumber air baku untuk RO mengandung mikroorganisme seperti mikroalga, bakteri dan jamur. Selain itu, sumber air baku RO tersebut juga mengandung nutrisi dan sumber energi yang mendukung pertumbuhan mikroorganisme yang ada di dalam air tersebut. Biofouling menjadi masalah utama dalam sistem RO. Hasil studi oleh laboratorium di Spanyol menunjukkan bahwa biofouling menjadi penyebab utama atau mencapai $35 \%$ dari kegagalan sistem membran yang diuji dalam periode 5 tahun. Penyebab biofouling lainnya adalah bahan partikulat koloid (29\%), deposit senyawa anorganik (29\%), dan penyebab lain yang tidak terdeteksi $(7 \%)$.
Efek biofouling terhadap membran RO yang menggunakan sumber air payau dan air laut diantaranya adalah tekanan yang semakin menurun, penurunan flux air, dan mempengaruhi mobilitas garam. Efek biofouling yang paling ekstrim adalah kegagalan sistem membran, sehingga diperlukan pretreatment tambahan untuk mengontrol populasi mikroorganisme dalam air hasil olahan RO (feed water), yang berakibat pada kenaikan biaya operasi. Namun demikian, aplikasi pre-treatment dan perlakuan kimiawi biasanya tidak mampu menghilangkan mikroorganisme dan nutrien dalam air produksi secara menyeluruh. Efektifitas kerja membran $\mathrm{RO}$ dalam menghilangkan mikroorganisme dan nutrien dalam air produksi ditentukan oleh desain sistem $\mathrm{RO}$, prosedur operasi yang digunakan dan kemampuan mikroorganisme untuk beradaptasi dalam lingkungan membran. Hal 
lain yang perlu diperhatikan adalah metode yang banyak digunakan saat ini untuk mengontrol biofouling dapat menginduksi pertumbuhan mikroba bila digunakan tidak sesuai prosedur.

Sistem RO, khususnya pada bagian pre-treatment, jaringan perpipaan dan membran $\mathrm{RO}$ memiliki luas permukaan yang besar yang digunakan oleh bakteri di dalam air baku untuk tempat melekat dan tumbuh. Bakteri yang melekat pada permukaan tersebut membentuk struktur biofilm berupa matriks senyawa polimer ekstraseluler (EPS) yang terdiri dari polisakarida, protein dan asam nukleat. Matriks EPS ini menyebabkan perubahan pada porositas, densitas, kadar air serta sifat muatan dan perlekatan dari biofilm. EPS meningkatkan kekuatan struktur dan daya lekat biofilm melalui tiga gaya yaitu gaya elektrostatik, ikatan hidrogen dan gaya dispersi London. Daya lekat dan elastisitas biofilm tersebut menyebabkan biofilm susah dihilangkan dari permukaan membran dan terlindungi dari biosida. Terlebih lagi keberadaan kation divalen $\mathrm{Ca}$ dan $\mathrm{Mg}$ dapat meningkatkan kekuatan biofilm dengan membentuk senyawa garam antara permukaan membran dengan sel-sel bakteri yang bermuatan negatif.

Pembentukan biofilm tidak terjadi secara merata di seluruh bagian sistem membran. Karena membran RO menyaring bakteri dan nutrien dari air baku, maka biofouling terjadi pada bagian wadah bertekanan. Namun demikian, pada kasus yang ekstrem pembentukan biofilm dapat terjadi di bagian air produksi (permeate water) yang terkontaminasi. Jangka waktu pembentukan biofilm bervariasi antara sistem $\mathrm{RO}$, dari beberapa hari hingga beberapa minggu. Pada sistem RO yang beroperasi menggunakan air baku mengandung mikroba, biofilm akan muncul dalam 3-5 hari setelah beroperasi.

\section{Upaya Mengatasi Biofouling}

Untuk menekan kejadian biofouling pada sistem membran $\mathrm{RO}$, dapat dilakukan dengan cara preventif yaitu bakteri dan nutrien dihilangkan dari air baku sebelum masuk ke sistem membran (pretreatment). Pre-treatment yang umum digunakan diantaranya menggunakan membran yaitu membran mikro filtrasi (MF) dan ultra filtrasi (UF). Namun demikian, pre-treatment tersebut hingga kini belum dapat sepenuhnya menghilangkan mikroba dari air baku. Sel bakteri yang lolos dari saringan meskipun dalam jumlah sangat sedikit dapat tumbuh dan berkembang biak sehingga menyebabkan biofouling. Cara lain adalah dengan menggunakan disinfektan, baik senyawa kimia maupun sinar UV. Faktor yang pelu dipertimbangkan pada saat mendesain metode disinfektan yaitu kualitas air baku (populasi bakteri, $\mathrm{pH}$ dan kandungan senyawa organik dan anorganik), waktu kontak dan jenis material membran.

Senyawa kimia yang umum digunakan sebagai disinfektan adalah klorin. Klorin banyak digunakan sebagai disinfektan di industri dan aplikasi domestik karena murah dan mudah diperoleh. Namun demikian, penggunaan klorin di sistem RO memiliki 
keterbatasan. Membran RO yang terbuat dari membran tipis poliamida sensitif terhadap klorin. Klorin pada konsentrasi $1 \mathrm{ppm}$ dapat merusak membran tersebut bila kontak dengan membran selama 200-1000 jam. Karena itu klorin harus dihilangkan sebelum masuk ke sistem RO dengan arang aktif ataupun sodium metabisulfit. Dengan demikian bakteri yang tumbuh di permukaan membran tidak dapat dihilangkan karena air baku tidak mengandung klorin. Selain itu, meskipun klorin efektif membunuh mikroorganisme, namun klorin tidak dapat menurunkan konsentrasi EPS yang telah terbentuk, penyebab dari biofouling. Di lain pihak, senyawa yang dapat menghilangkan EPS, bukan termasuk disinfektan sehingga penggunaan senyawa tersebut untuk menghilangkan lapisan biofilm hanya bersifat sementara karena bakteri akan tumbuh membentuk biofilm kembali.

\section{Kesimpulan dan Implikasi}

Dengan semakin meningkatnya kebutuhan akan ARSINUM, maka tuntutan aspek kesehatan dari produk tersebut semakin meningkat pula. Berdasarkan berbagai hasil penelitian mengenai kualitas ARSINUM, keberadaan bakteri coliform dan patogen lainnya dalam ARSINUM dari dispenser patut menjadi perhatian. ARSINUM yang dihasilkan hendaknya diperiksa dan dirawat secara periodik untuk mencegah penyebaran mikroorganisme patogen. Dua hal yang dapat dilakukan untuk menurunkan potensi lolosnya bakteri ke dalam air produksi setelah filtrasi dengan membran $\mathrm{RO}$ diantaranya yaitu: (1) seal Ring-O yang digunakan sebaiknya memiliki kualitas yang tinggi serta pemasangannya dilakukan secara hati-hati dan benar untuk menghindari kebocoran, dan (2) permukaan membran perlu dijaga agar tidak rusak pada saat pemasangan.

Berbagai jenis permukaan dalam unit pengolahan ARSINUM seperti stainless steel, material membran, dan plastik menjadi tempat melekat dan berkembangbiak bakteri hingga terbentuk biofilm. Permukaan membran RO yang berpori sangat ideal untuk menahan partikel anorganik dan bakteri yang selanjutnya membentuk biofilm. Larutan klorin dapat menurunkan populasi bakteri namun tidak begitu efektif menghilangkan biofilm. Karena itu, waktu kontak antara klorin dengan biofilm dan mikroorganisme perlu dikaji lebih lanjut untuk menghilangkan bakteri secara signifikan. Hidrogen peroksida cukup efektif dalam mencegah dan menghilangkan biofilm dalam waktu 1-2 menit setelah kontak.

\section{Daftar Pustaka}

Al Moosa, M. E., Khan, M. A., Alalami, U., \& Hussain, A. 2015. Microbiological quality of drinking water from water dispenser machines. International J.Environ.Sci.Dev., 6(9): 710.

Baba, T., Matsumoto, R., Yamaguchi, N., \& Nasu, M. 2009. Bacterial population dynamics in a reverse-osmosis water purification system 
determined by fluorescent staining and PCR-denaturing gradient gel electrophoresis. Microbes and Environments, 0904230083-0904230083.

Belila, A., El-Chakhtoura, J., Otaibi, N., Muyzer, G., Gonzalez-Gil, G., Saikaly, P.E., \& Vrouwenvelder, J.S. 2016. Bacterial commu-nity structure and variation in a full-scale seawater desalination plant for drinking water production. Water Res., 94: 62-72.

Bixler, G. D., \& Bhushan, B. 2012. Biofouling: lessons from nature. Phil. Trans. Royal Soc. A: Mathematical, Physical and Engineering Sciences, 370(1967): 2381-2417.

Douterelo, I., Sharpe, R. L., Husband, S., Fish, K. E., \& Boxall, J. B. 2019. Understanding microbial ecology to improve management of drinking water distribution systems. Wiley Interdisciplinary Reviews: Water, 6(1): 01325.

El-Chakhtoura, J., Prest, E., Saikaly, P., van Loosdrecht, M., Hammes, F., \& Vrouwenvelder, H. 2015. Dynamics of bacterial communi-ties before and after distribution in a fullscale drinking water network. Water Research, 74: 180-190.

Farhadkhani, M., Nikaeen, M., Adergani, B.A., Hatamzadeh, M., Nabavi, B.F. \& Hassanzadeh, A. 2014. Assessment of drinking water quality from bottled water coolers. Iranian Journal Of Public Health. 43(5): 674-81.

Liguori, G., Cavallotti, I., Arnese, A., Amiranda, C., Anastasi, D. \& Angelillo, I.F. (2010) Microbiological quality of drinking water from dispensers in Italy. BMC microbiology 10(1),

Fujioka, T., Oshima, N., Suzuki, R., Khan, S. J., Roux, A., Poussade, Y., \& Nghiem, L.D. 2013. Rejection of small and uncharged chemicals of emerging concern by reverse osmosis membranes: The role of free volume space within the active skin layer. Separation and Purification Technology, 116: 426-432.

Fujioka, T., Hoang, A. T., Aizawa, H., Ashiba, H., Fujimaki, M., \& Leddy, M. 2018. Real-time online monitoring for assessing removal of bacteria by reverse osmosis. Environ.Sci. Technol.Lett., 5(6): 389-393.

Fujioka, T., Hoang, A.T., Ueyama, T., \& Nghiem, L.D. 2019. Integrity of reverse os-mosis membrane for removing bacteria: new insight into bacterial passage. Environmental Science: Water Research \& Technology, 5(2): 239-245.

Goosen, M. F. A., Sablani, S. S., AlHinai, H., Al-Obeidani, S., Al- 
Belushi, R., \& Jackson, A. 2005. Fouling of reverse osmosis and ultrafiltration membranes: a critical review. Separation Sci. and Technol., 39(10): 2261-2297.

Hashim, N. H., \& Yusop, H. M. 2016. Drinking water quality of water vending machines in Parit Raja, Batu Pahat, Johor. In IOP Conference Series: Materials Science and Engineering (Vol. 136, No. 1, p. 012053). IOP Publishing.

Laurent, P., Servais, P., Gatel, D., Randon, G., Bonne, P., \& Cavard, J. 1999. Microbiological quality before and after nanofiltra-tion. J. American Water Works Association. 91(10): 62-72.

Liguori, G., Cavallotti, I., Arnese, A., Amiranda, C., Anastasi, D., \& Angelillo, I.F. 2010. Microbiological quality of drinking water from dispensers in Italy. BMC Microbiology, 10(1) : 19 .

Park, S.K. and Hu, J.Y. 2010. Assessment of the extent of bacterial growth in reverse osmosis system for improving drinking water quality. $J$. Environ. Sci. Health A Tox. Hazard Subst. Environ. Eng. 45: 968-977.

Penna, V.T.C., Martins, S.A.M., \& Mazzola, P. G. 2002. Identification of bacteria in drinking and purified water during the monitoring of a typical water purification system. BMC Public Health, 2(1) : 13 .

Prest, E.I., Weissbrodt, D.G., Hammes, F., Van Loosdrecht, M.C.M., \& Vrouwenvelder, J. S. 2016. Long-term bacterial dynamics in a full-scale drinking water distribution system. PLoS One, 11(10).

Wibuloutai, J., Thanomsangad, P., Benjawa-nit, K., \& Mahaweerawat, U. 2019. Microbial risk assessment of drinking water filtration dispenser toll machines (DFTMs) in Mahasa-rakham province of Thailand. Water Science and Technology: Water Supply.

Yongyod, R. 2018. Drinking water quality and evaluation of environmental conditions of water vending machines. AsiaPacific J.Sci.Technol., 23(1).

Zhou, X., Zhang, K., Zhang, T., Li, C., \& Mao, X. 2017. An ignored and potential source of taste and odor (T\&O) issuesbiofilms in drinking water distribution system (DWDS). Appl. Microbiol. Biotechnol., 101(9): 3537-3550. 